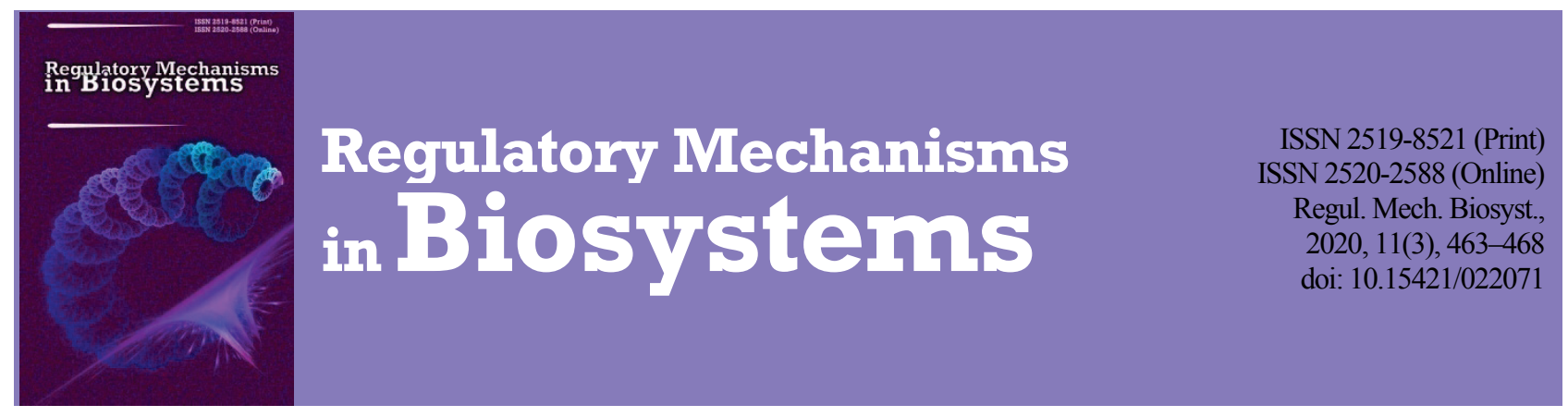

\title{
Micromorphology and anatomy of the flowers of Galanthus nivalis and Leucojum vernum (Amaryllidaceae)
}

\author{
O. S. Fishchuk*, A. V. Odintsova** \\ *Lesya Ukrainka Eastern European National University, Lutsk, Ukraine \\ **Ivan Franko National University of Lviv, Lviv, Ukraine
}

Article info Fishchuk, O. S., \& Odintsova, A. V. (2020). Micromorphology and anatomy of the flowers of Galanthus nivalis and Leucojum vernum
(Amarylidaceae). Regulatory Mechanisms in Biosystems, 11(3), 463-468. doi:10.15421/022071

Received 11.07.2020

Received in revised form 19.08.2020

Accepted 20.08.2020

Lesya Ukrainka

Eastern European

National University,

Volipr., 13,

Lutsk, 43025, Ukraine.

Tel.: $+38-066-310-81-07$

E-mail:

dracaenaok@ukr.net

Ivan Franko National

University of Lviv,

Grusherskogo st., 4,

Lviv, 79005, Ukraine.

Tel.: +38-097-937-28-69.

E-mail:amorpha@ukr.net

We studied the structure of flowers of Galanthus nivalis and Leucojum vernum using cross-sections and longitudal sections of permanent preparations using a light microscope. Genera Galanthus and Leucojum belong to the Galantheae tribe characterized by a unique combination of features of the family Amaryllidaceae, i.e. absence of septal nectaries, poricidal anthers and fruit - fleshy capsule. Both species are represented in the flora of Ukraine and have the life form of bulb ephemeroid of decidous forests. Microscopic surveys of flowers are considered as an instrument for determining yet unknown structural adaptations of plants to specialized ways of pollination and determining the first stages of morphogenesis of fruit, because many features of the fruit appear already at the stage of flower. We determined that the tepals of both studied species have multi-bundle traces of 8-9 vascular bundles. Apical dehiscence of the anthers occurs due to short longitudinal sutures in the upper part of the anthers. The nectar disk on the roof of the inferior ovary is poorly differentiated, and has no vascular bundles. We associate the indicated peculiarities of the flower structure with the offer of pollen as the main reward of the pollinator during buzz-polination, which has not reported for the studied species. Placentation is axile in the lower part of the ovary and parietal in the upper one. We consider that the gynoecium of the studied species is eusyncarpous. The vascular system of the inferior ovary is composed of three dorsal and three septal veins, paired ventral bundles of carpels, which form the traces of ovules, and also small additional bundles in the wall of the ovary. For the first time, we have determined the presence of airy parenchyma in the ovules, ovary roof, the style and anthers' connectives and have confirmed their presence in the tepals and the wall of the ovary at the stage of flowering. We found differentiation of the mesocarp into photosynthesizing and airy parenchyma, small sizes of cells of the endocardium in the area of the dorsal vein, bifurcate dorsal bundles of the carpels, which could be considered as adaptation of different stages of morphogenesis of fruit to dehiscence. Anatomical peculiarities of the ovaries of $G$. nivalis and $L$. vernum: numerous vascular bundles in the pericarp, thick parenchyma mesocarp with airfilled cavities, non-lignified endocarp at the stage of the flower we consider adaptations to the formation of fleshy fruit. The new data we obtained on the anatomical structure of the flowers is a significant addition of information about anthecological and carpological (postanthetic) peculiarities of the surveyed species.

Keywords: nectary; fruit morphogenesis; anther dehiscence; buzz-pollination.

\section{Introduction}

The contemporary systematics of monocotyledons is based on molecular data and in its development is the basis for the taxonomic systems. Molecular-phylogenetic analysis does not take into account such important peculiarities of the flower's structure as presence and height of the zones of the ovary, number of ovules in the locule, features of vascular anatomy of the flower and structure of septal nectaries. Integration of the data of molecular phylogenetics and comparative evolutionary morphology of the flower is a promising direction for the creating of the contemporary evolutionary system of orders, families, subfamilies and genera. Study of micromorphology and vascular anatomy of the flower of monocots is a contemporary method of the study of evolutionary morphology (Fishchuk et al., 2013; Nuraliev \& Sokoloff, 2014, Odintsova \& Fishchuk, 2017). Molecular-phylogenetic reconstructions of the Amaryllidaceae J. St.Hil. family have been made by a number of scientists, among them the most active are Meerow et al. (2006), Chase et al. (2009), García et al. (2019).

As the objects of our study we selected Galanthus nivalis L. and Leucojum vernum L., which are present in the flora of Ukraine and widely cultivated as ormamental plants. The genera Galanthus L. and Leucojum L. belong to the tribe Galantheae Salisb., subfamily Amaryllidoideae s.s., family Amaryllidaceae (Chase et al., 2009; Takhtajan, 2009; Chase et al., 2016). Data of molecular systematics of the surveyed genera confirm the monophyly of the tribe (Lledó et al., 2004). The genus Galanthus L. comprises 20 species of herbaceous bulb perennial plants distributed from the Spanish and the French Pyrenees in the west to the Caucasus and Iran in the east, and in the north to Sicily, the Peloponnese, Aegean Sea, Turkey, Lebanon and Syria, while being native to Europe and the Near East. The northern border of the genus is indefinite, because $G$. nivalis is broadly introduced and cultivated throughout Europe (Takhtajan, 2009). The characteristic features of the genus are one-two-flowered generative shoots, free tepals, short stamen filaments, basifix anthers, capitate stigma and somewhat fleshy capsule (Meerow \& Snijman, 1998).

Flowers of Galanthus nivalis L. are $2.0-2.5 \mathrm{~cm}$ long. The perigonium consists of 6 tepals arranged in two circles. Aestivation of the outer tepals is open, and of the inner tepals is valvate. The tepals of the inner circle are broad-lanceolate, concave on both sides, $1.6-1.7 \mathrm{~cm}$ in length and 0.8 $0.9 \mathrm{~cm}$ in width, respectively. The tepals of the inner circle are shorter than the outer ones, obcordate, with a notch at the apex with green spots, 0.9 $1.0 \mathrm{~cm}$ in length and $0.5-0.6 \mathrm{~cm}$ in width. The stamens of the outer circle are on average $0.7-0.8 \mathrm{~cm}$ in length, while the stamens of the inner circle are $0.60-0.65 \mathrm{~cm}$ long, have stamen filaments enlarged downwards to the base. The stamen filaments are on average $0.05 \mathrm{~cm}$ in diameter. The anthers are linear, narrow-triangular, sharpened at the apex and open from the top; the anthers of the outer circle are $0.50-0.55 \mathrm{~cm}$ long, the anthers of the inner circle are $0.40-0.45 \mathrm{~cm}$ long and $0.1 \mathrm{~cm}$ wide. The ovary of 
G. nivalis is oblong, trilocular, $0.5 \mathrm{~cm}$ in height and $0.3 \mathrm{~cm}$ in diameter. The style is linear, filamentary, around $0.60 \mathrm{~cm}$ in length and $0.05 \mathrm{~mm}$ in diameter, covered by papilous epidermis. The stigma is small, capitate, $0.10 \mathrm{~cm}$ in height and $0.005 \mathrm{~cm}$ in diameter.

The genus Leucojum L. is a small genus of bulb herbaceous plants, native to Eurasia. The genus comprises only two species $-L$. aestivum $\mathrm{L}$. and $L$. vernum $\mathrm{L}$., and 10-11 species according to other data (Meerow \& Snijman, 1998). Until 2004, the Leucojum contained two species which are now classified to genus Acis Salisb. Compared to Acis genus, Leucojum has flat peduncles, aerenchyma in the flower-bearing shoots, white tepals bear green or yellow spots both on the inner and outer three tepals, the seeds are larger in size. Leucojum have broad linear leaves, similarly to the related genus Galanthus, but not the narrow leaves like the representatives of Acis (Lledó et al., 2004). Flowers of $L$. vernum are up to 2.5-2.9 $\mathrm{cm}$ long, white with green spots at the apices of the tepals. The peduncle is $15-21 \mathrm{~cm}$ long and $0.3 \mathrm{~cm}$ in diameter, the inflorescence is composed of 1-2 flowers. There are two cone-shaped bracts, $2.1-2.2 \mathrm{~cm}$ long, 0.7-0.8 $\mathrm{cm}$ wide and $0.20-0.25 \mathrm{~cm}$ near the basis, coriaceous, light-brown.

The tepals are free. The outer tepals are broad-lanceolate with sharpened apex of $1.6-1.7 \mathrm{~cm}$ long and $0.8-0.9 \mathrm{~cm}$ in width, and the inner tepals have the same shape as the outer ones, but are of the same length and width measuring $1.3-1.4$ and $0.7-0.8 \mathrm{~cm}$ respectively. The stamens have white filaments of 0.65 and $0.75 \mathrm{~cm}$ long, the inner stamens are longer. The outer stamen filaments are $0.15-0.16 \mathrm{~cm}$, and the inner stamen filaments are $0.20-0.25 \mathrm{~cm}$ long. The anthers are bright yellow, elongated, triangular, dull at the apex, open at the top. The anthers of the outer stamens are $0.50 \mathrm{~cm}$ long, and the anthers of the inner stamens are $0.55 \mathrm{~cm}$ long. The anthers are $0.13 \mathrm{~cm}$ in the diameter. The gynoecium of L. vernum has an elongated bright-green ovary of $0.90 \mathrm{~cm}$ high and 0.25 $0.30 \mathrm{~cm}$ in diameter, which continues into the spindle-shaped style of 0.80 $\mathrm{cm}$ length with clavate green stigma. The fruit of the two species is a fleshy loculicidal capsule which opens from the top downward. The seeds are round, with large juicy elaiosome (Meerow \& Snijman, 1998; Takhtajan, 2009). The seed of representatives of Galanthus genus has a phytomelanin "crust" formed of exotesta and several underlying layers of the integument, has a chalazal appendage (Takhtajan, 2009). In Ukraine, there are three species of Galanthus genus ( $G$. elwesii Hook. f., G. nivalis L., $G$. plicatus M. Bieb.) and two species of Leucojum genus ( $L$. aestivum L. and L. vernum L.) (Mosyakin \& Fedoronchuk, 1999).

Of relevance is the study of ecophysiology of the dormancy of the seeds and control of their germination at the beginning of the spring blossoming in G. nivalis (Newton et al., 2015), bioactive substances, particularly alkaloid galantamine (Berkov et al., 2012), vegetative and generative reproduction of snowdrops, impregnation, microsporogenesis, macrosporogenesis, development of seeds and fruits (Erdelská, 2018), potential of germination of pollen and growth of the pollen tubes in the conditions of low and high temperatures in nutritive media (Padureanu \& Patras, 2020). Cytogeographical surveys of Leucojum genus have been conducted (Bareka et al., 2003; Lipnicki \& Gruszka, 2019). Studies have been performed concerning synchronicity in the phenology of spring flowers, particularly L. vernum (Sparks et al., 2012). Biochemical and micromorphoanatomical surveys of $L$. aestivum $\mathrm{L}$. were undertaken by the Turkish scientists (Al-Faris et al., 2019; Arslan et al., 2020). The study of the morphometric parameters revealed the correlation relationships between the maximum length of the leaf and length of the stem, and also maximum length of the leaf and the bract (Kohut et al., 2019).

Therefore, although the question of reproductive biology, taxonomy and geography of $G$. nivalis $\mathrm{L}$. and $L$. vernum $\mathrm{L}$. have attracted the attention of contemporary scientists, they remain poorly studied in terms of the anatomy of the flower, which are important for the analysis of pollination and post-anthetic morphogenesis (formation and opening of the fruit). The objective of our study was determining the peculiarities of morphology of the flower and the internal structure of the gynoecium and determining its vertical zoning in the representatives of the Amaryllidaceae family.

\section{Material and methods}

The flowers of G. nivalis and $L$. vernum were studied in the stage of the floral bud and opened flower. The material was collected in the
A. V. Fomin Botanical Garden of the Taras Shevchenko National University of Kyiv and fixated in $70 \%$ ethanol. Out of the fixated material we prepared the preparations of a series of cross-sections of the flowers of $20 \mu \mathrm{m}$ thick, using the standard method (Barykina et al., 2004). The sections were stained using astra blue solutions and safranine. We studied five flowers of each species. To describe the preparations we used a Laboval 4 optical microscope manufactured by Carl Zeiss (Jena) and a stereoscopic binocular microscope MBS- 10 .

To analyze the internal structure of the gynoecium, we used the concept of vertical zonation of gynoecia of Leinfellner (1950) which takes into consideration only the congenital fusion of the carpels. According to this concept, with growth of the carpels, in the syncarpous gynoecium, congenital multi-locular synascidiate, unilocular simplicate, transitional hemi-simplicate and asymplicate (apocarpous) zones form. In the conditions of incomplete fusion of carpels, a hemi-syncarpous gynoecium with hemi-synascidiate, hemi-simplicate and asymplicate zones form only in their external part. The height of the zones of gynoecium was measured according to the number of cross-sections. The methodological basis of study of the vertical zonation of the gynoecium was formulated by Leinfellner (1950), later the method was elaborated for monocots (Novikov \& Odintsova, 2008; Shamrov, 2010; Odintsova, 2013). Post-anthetic changes in the structure of the flowers were analyzed according to Roth (1977).

\section{Results}

Galanthus nivalis. The locule contained 14 ovules, arranged in two rows (Fig. 2d, e), having a funicular obturator (Fig.1a). In the gynoecium of $G$. nivalis, we distinguished the following structural zones: a fertile multi-locular zone of around $860 \mu \mathrm{m}$ height, which corresponds to the synascidiate structural zone (Fig. 2c, d) and fertile simplicate structural zone, the height of which was around 3,540 $\mu \mathrm{m}$ (Fig. 2e). The hemisimplicate zone was absent. The style along the entire length is formed by the simplicate zone (Fig. 2f, g). Incomplete septa of the ovary in the simplicate zone were not split radially, their epidermis densely adjoins the epidermis of the neighboring septa in the center of the ovary (Fig. 3b), which means the absence of septal nectar slit. The nectaries are in the form of nectary disk located between the stamens and the style (Fig. 1a). In the cross sections (Fig. 2h), it was seen that the inner tepals are thicker than the outer ones and have longitudinal folds on the inner surface, and that the anthers open in their apical part as longitudinal sutures split, and are covered with papilous exotecium (Fig. 3d).

The wall of the ovary's parenchyma, the external epidermis, was formed out of isodiametric cells with thickened walls (Fig. 3a, c). The internal epidermis contains flattened non-lignified cells which in the area of the dorsal vein are small (Fig. 3c). The external and internal epidermis of the ovary contains stomata (Fig. 3a, c). Mesophyll of the ovary is parenchymal, contains $12-15$ layers of cells, differentiated into the external dense photosynthesizing zone and the zone of airy parenchyma. Notable air-bearing cavities [or aerial ducts] are present in the pedicel and in the external parts of the flower (Fig. 2). They are located in the cortex of the pedicel (Fig. 2a), in the mesophyll of tepals (Fig. 2g, h), in the middle and internal zones of the mesocarp, in the style of the pistil (Fig. 2h, 3d), in the stamen filaments and the stamens' connectives (Fig. 3d), the ovary roof (Fig. 2f) and even the ovules (Fig. 3c). The upper part of the pedicel, the base of the flower tube, the stamen filaments and the wall of the ovary, connective and the style contain idioblasts with cellular inclusions - raphides (Fig. 6c, d). In the free apices of the tepals they are absent.

The pedicel of $G$. nivalis L. contains a central cylinder composed of 9 vascular bundles (Fig. 2a), which in the basis of the ovary reorganize in 12 groups of bundles surrounded by airy parenchyma (aerenchyma) of the cortex and the pith (Fig. 2b). Three bundles located at the radii of the septa of the ovary (septal bundles) ramify towards the center, forming a triangle of vascular bundles (Fig. 2c), and from the triangle, ventral bundles ramify, providing nutrition to the ovules.

At different heights of the ovary, from the septal bundles, small bundles ramify which extend through the septa to the placentae and also provide nutrition to the ovules. Therefore, in the central columne, a circle of 6 ventral bundles of carpels forms (Fig. 2d). In the wall of the ovary, apart from the septal veins, there are three dorsal veins which run across the 
median areas of the carpels, and 6 additional bundles which alternate with septal and dorsal veins. All veins in the wall of the ovary can comprise one or 2-3 bundles - this is especially noticeable in the dorsal veins, which in the apical part of the ovary divide into the middle bundle of the tepal, trace of the stamen and dorsal bundle of the carpel (Fig. 3c). The dorsal bundle of the carpel is composed of two halves, i.e. is double. Septal veins in the ovary roof divide into the middle bundle of the tepal and trace of the stamen (Fig. 3a). The traces of the stamen are single-bundled, the traces of the outer and inner tepals have 8-9 bundles (Fig. $2 \mathrm{~h}$ ). Above the locules, the ventral bundles of the carpel unite with the dorsal bundles, forming three veins which run into the style (Fig. 2h, 4d).

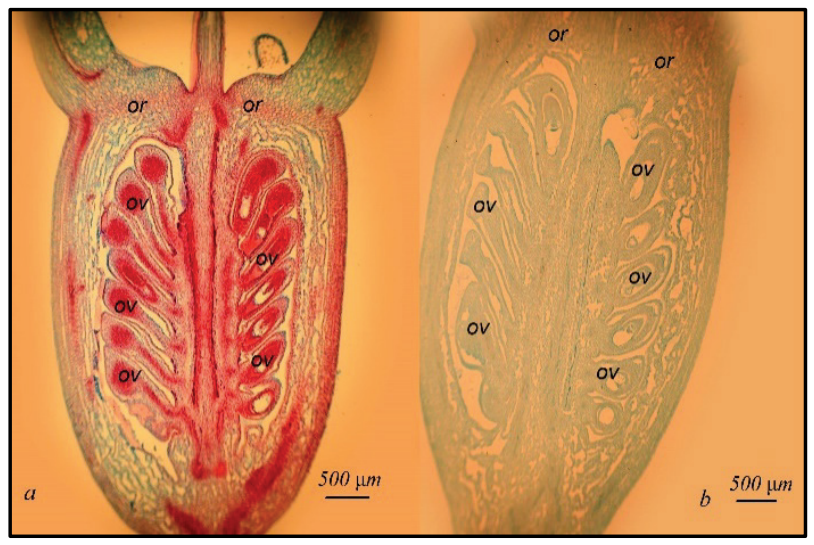

Fig. 1. Longitudinal sections of the ovary of Galanthus nivalis (a) and Leucojum vernum (b): ov - ovule; or-ovary roof; on a slightly differentiated nectary discus is visible

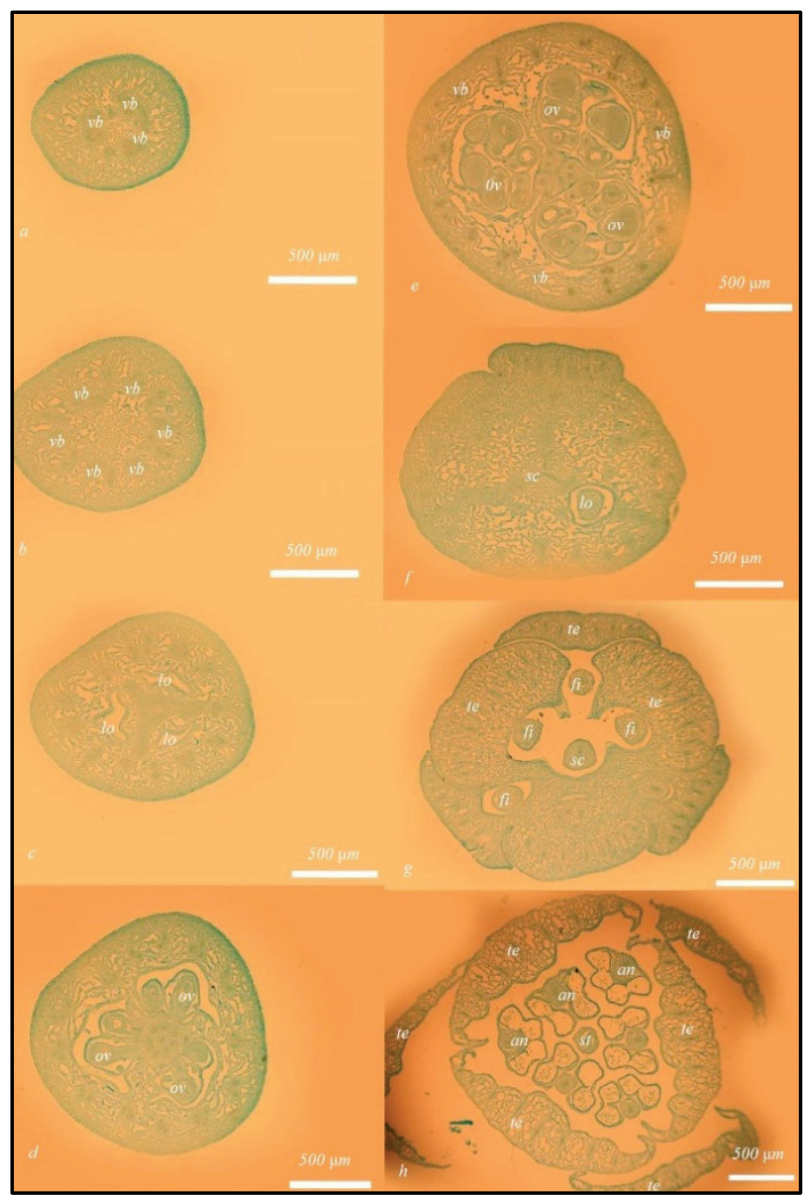

Fig. 2. Ascending series of transversal sections of the flower Galanthus nivalis: $a-b$-pedicel; $c-f$-inferior ovary; $c-d$-synascidiate zone, $e$-symplicate zone; $f$ - ovary roof; $g$ - floral organs' insertion, $h$ - free tepals, anthers and style; $a n$ - anther; $f$ - filament; $l o$ - ovary locule; $o v$ - ovule; $s c$ - style channel; st-style; te-tepal; $v b$ - vascular bundle
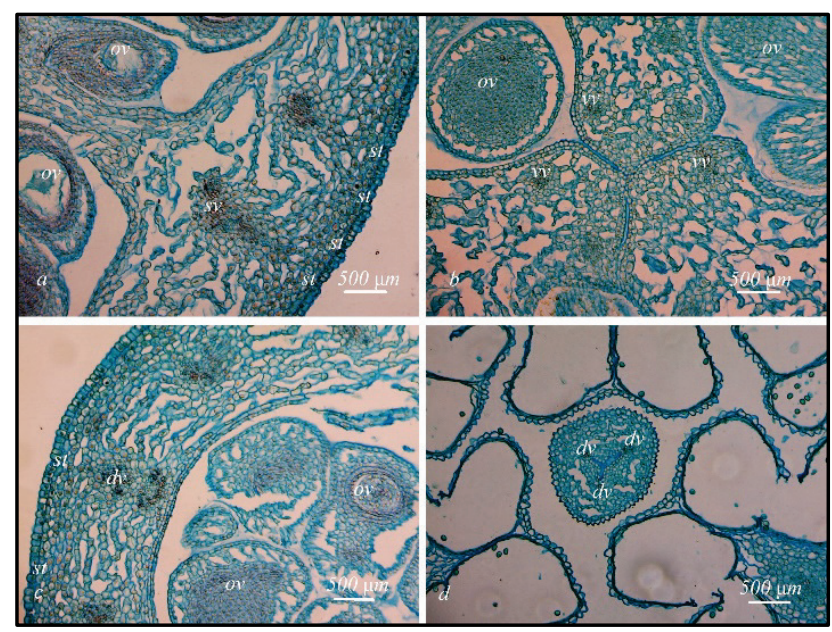

Fig. 3. Floral parts of Galanthus nivalis: $a$ - ovary wall with septa attached, note numerous stomata, septal vascular bundle and additional bundles in wall aerial parenchyma; $b$-central part of the ovary, free ends of septa, filled by aerenchyma, are closely connected, paired ventral vascular bundles are visible, no stylar channel presents; $c$ - ovary wall in the median part of the carpel, numerous stomata, dorsal vein composed of two bundles and additional veins are visible; note small cells of the inner ovary epidermis in the plane of dorsal vein; $d$-style and anthers, triradial style channel and dorsal veins are visible as also papillate epidermal cells of the style and anthers;note aerial parenchyma in ovules (on $a, b, c$ ), connectives and style (on $d$ ); $d v$-dorsal vein; $o v$ - ovule; st - stomata;

$$
s v \text { - septal vein; } v v \text { - ventral vein }
$$

Leucojum vernum. In the gynoecium of $L$. vernum we distinguish the following structural zones: fertile synascidiate structural zone (Fig. 4c, d) of about $500 \mu \mathrm{m}$ height and fertile simplicate structural zone of around $3,720 \mu \mathrm{m}$ (Fig. 4e, f). Hemi-simplicate zone is absent. The style, similarly to the previous species, is formed from the simplicate zone. The septal nectary sutures are absent, but in the center of the ovary, in the simplicate zone, there forms a triradial cavity between the ends of incomplete septa (Fig. 4e, 5a) which continues into the style, where it forms the style channel (Fig. 4g). There are 12 and more ovules in the cell, arranged in two rows, and the obturator is funicular (Fig. 1b). On the ovary roof there is a weakly noticeable nectary disk.

The wall of the ovary is parenchymal, the external epidermis of the ovary is formed of isodiametric cells with thickened walls (Fig. 5b, c). The mesophyll of the ovary contains 15-16 layers of cells, differentiated in the same way as in the previous species. Airy parenchyma fills all the organs of the flower. The base of the flower tube, the stamen filaments and the wall of the ovary, free apices of the tepals contain idioblasts with cellular inclusions - raphides (Fig. 6a, b). They are absent in the apical part of the pedicel and the style.

The pedicel contains 10 vascular bundles, aerenchymal cortex and the pith (Fig. 4a). In the base of the ovary, the bundles reorganize in three concentric circles. The outer circle is formed of 9-10 groups of bundles, which continue into the wall of the ovary, form traces of the tepals and stamens. The middle circle is divided into three groups of septal bundles located in the septa of the ovary. The inner circle of bundles runs into the central column of the ovary and forms ventral bundles of the carpels which, together with the septal bundles, provide nutrition to the ovules (Fig. 4b). The dorsal vascular bundles of the carpels are doubled, and form similarly to those in G. nivalis (Fig. 4d, e). Above the cells of the ovary, the ventral bundles of the carpel and also the paired bundles in the septa unite with the dorsal bundles and form the dorsal vein. The traces of the outer tepals comprise 9 vascular bundles, the traces of the inner tepals -8 vascular bundles (Fig. 4g, h). The traces of the stamens are single-bundled, form from the bundles of the ovary wall (Fig. 4h).

\section{Discussion}

The studied species were characterized by significant similarity of morphological-anatomical structure of the flower, differing only by the 
proportions of the flower organs. The tepals of the both species were not found to grow together; they innervate by many vascular bundles and contain aerenchyma. The tepals of the outer and inner circles vary in sizes and thickness much more in G. nivalis than in L. vernum. Earlier, using SEM microscopy and histological methods (Weryszko-Chmielewska \& Chwil, 2010), it was found that in G. nivalis, in the adaxial surface of the inner tepals, has green airy stripes located between the vascular bundles and covered by numerous stromata. The abaxial surface of the upper parts of the tepals is characterized by cone papillae with striped cuticle. The stromata are located between the papillae. The chlorenchyma, under adaxial epidermis, is composed of 1-2 layers of isodiameteric cells. The middle part of young tepals of the perianth is occupied by parenchyma (34 layers), whereas in older tepals, large air ducts form in the area of protrusions (Weryszko-Chmielewska \& Chwil, 2010). The surveys on the cross section of a fresh tepal under the fluorescent microscope, made using red filter, revealed intense fluorescence of the epidermal cells located on the edges of the tepal of the perianth, confirming their associated with production of scent (Weryszko-Chmielewska \& Chwil, 2010). The abovedescribed structural peculiarities of the epidermal cells of the tepals of $G$. nivalis indicate that this tissue of the tepal forms a layer characteristic for osmophores - structures which produce volatile substances in flowers.

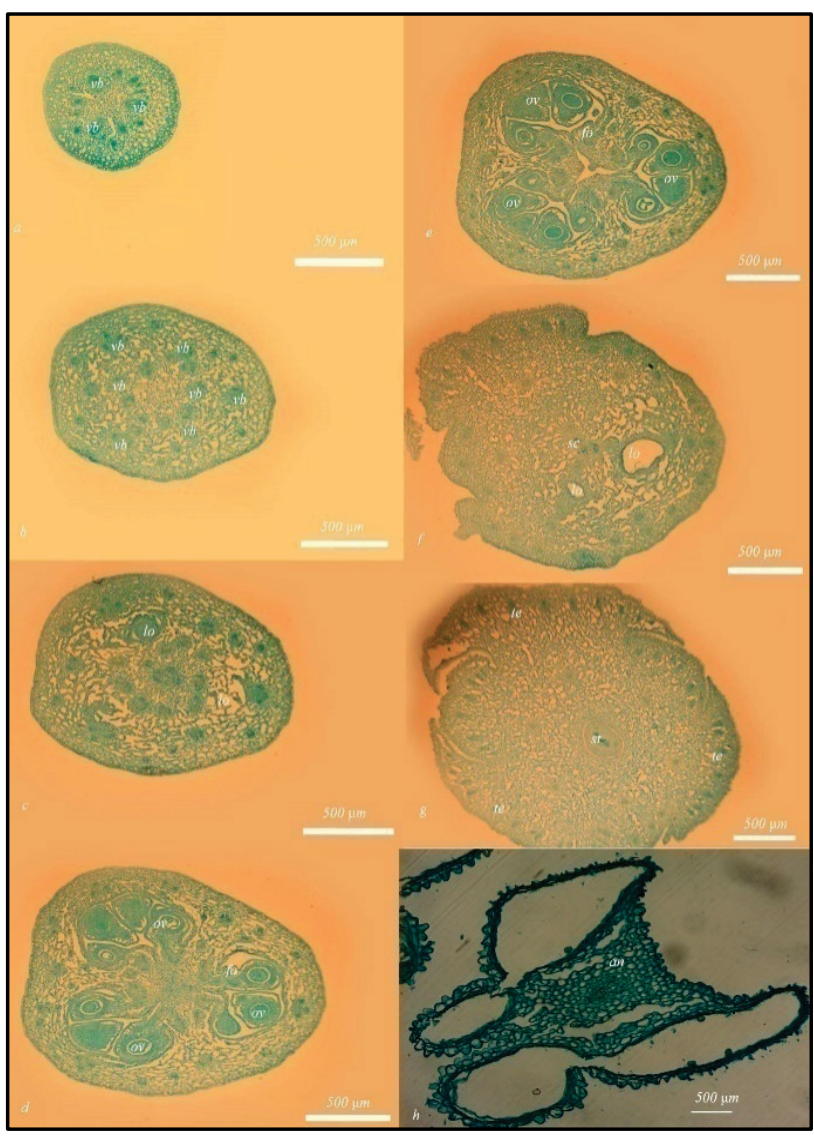

Fig. 4. Ascending series of transversal sections of the flower Leucojum vernum: $a$-pedicel; $b-g$-inferior ovary; $b$-ovary base; $c, d$-synascidiate zone; $e$-symplicate zone; $f, g$ - ovary roof; $h$ - anthers; $f o$ - funicular obturator; $l o$ - ovary locule; $o v$ - ovule; $s c$ - style channel; st - style; te-tepal; $v b$ - vascular bundle

Genera Galanthus and Leucojum are described regarding diagnostic features of stamens: anthers are basifixed, open in the apical pores (Meerow \& Snijman, 1998), though as shown in Fig. 24 and 41 in the study by Artjushenko (1970), the anthers of these representatives of the genera open apically due to short longitudinal sutures, as indicated in the data obtained in our study, particularly, cross sections of flower in the apex of the anther. Therefore, dehiscence of the anthers through the apical pores in Galanthus and Leucojum could be considered as an extremely specialized variant of lengthwise splitting open of short sutures in the apical part of the anthers, which is possibly attributed to the pendant position of flowers.
In the apical part of the ovary, between the filaments and the style, there is located a disk-like nectary which forms a bright layer in contrast to the green ovary. The size of the nectary disk in Galanthus was found to increase with increase in the sizes of the perigonium (WeryszkoChmielewska \& Chwil, 2010). The nectar is seen already in the floral bud; it accumulates in the space between the stamen filaments and the style, being noticeable up to the height of the anthers, where it contacts with their adaxial surface (Weryszko-Chmielewska \& Chwil, 2010).

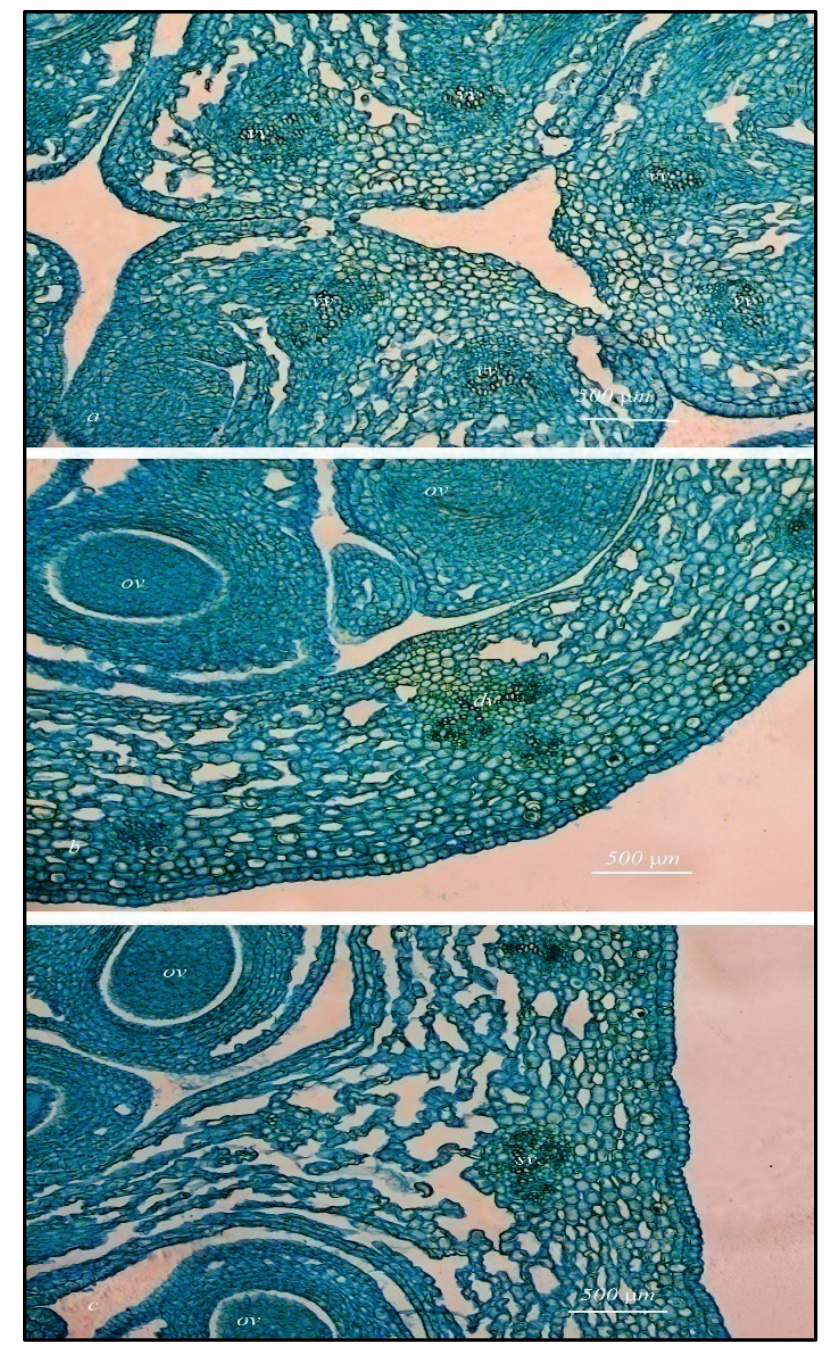

Fig. 5. Floral parts of Leucojum vernum: $a$ - central part of the ovary, septas free ends, filled by aerenchyma, form a triradial channel, paired ventral vascular bundles, stomata on the inner epidermis of septa marked with arrow; $b$-ovary wall in the median part of the carpel, note stomium, dorsal vein composed of two bundles and additional veins are visible; the inner part of dorsal vein is bifurcated; note small cells of the inner ovary epidermis in the plane of dorsal vein; note aerial parenchyma in ovules; $c$ - ovary wall with septa attached, note septal vascular bundle and additional bundles in wall aerial parenchyma; $d v$-dorsal vein;

$$
o v \text {-ovule; } s v \text { - septal vein; } v v \text { - ventral vein }
$$

According to Daumann (1970), the genera Galanthus and Leucojum have disk-like nectaries. In general, the Amaryllidaceae family is characterized by septal nectaries, which are absent in Galantheae tribe (Daumann, 1970; Meerow \& Snijman, 1998; Takhtajan, 2009). Dauman determined the absence of septal nectaries even in the rudimentary condition in all the studied species of Galanthus and Leucojum genera. He has also confirmed the presence of a poorly differentiated nectary disk with a small amount of nectar. Nectar is removed through the cuticle of small-celled epidermis of the nectary. G. nivalis was found to have some features of perigonal nectaries at the top of inner tepals.

Monocotyledons were determined to have some patterns of the nectaries in common, i.e. absence of a nectary disk in the flowers with superior 
ovary, production of nectar through the cuticle and not through the nectary stoma, broad distribution of septal nectaries among the lilioid monocots and their frequent replacement with perigonal nectaries or change in the type of reward to the pollinator and type of flower ranging from nectarflower to pollen-flower (Smets et al., 2000). The indicated tendencies could be considered as having caused the origin of non-nectary or almost non-nectary flowers of $G$. nivalis and $L$. vernum.

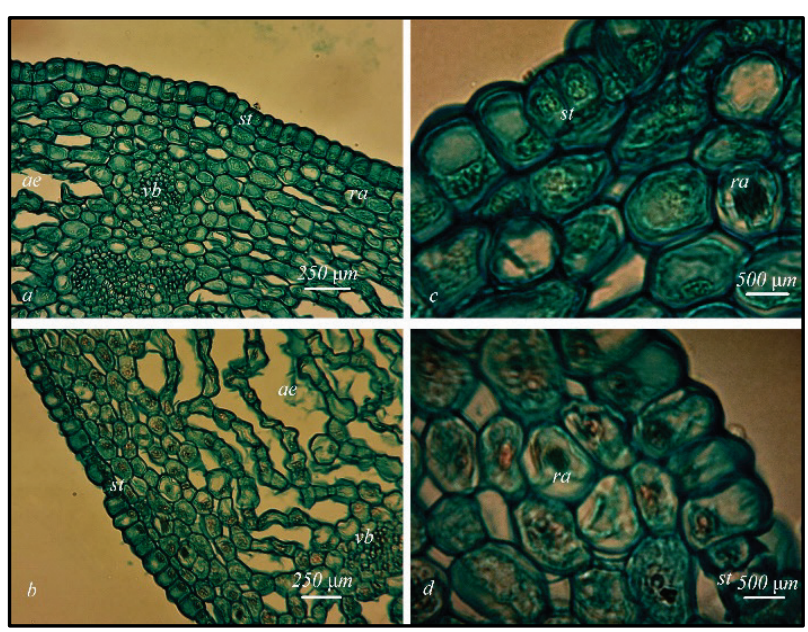

Fig. 6. Raphides and stomata in the distal parenchyma of the ovary wall of Leucojum vernum $(a, b)$ and Galanthus nivalis $(c, d)$ : ae - aerenchyma; $r a$-raphides; $s t$ - stomata; $v b$-vascular bundle

For the Amaryllidaceae family, axile placentation is indicated (Meerow \& Snijman, 1998). Our research revealed that the ovules in G. nivalis and $L$. vernum are located in both zones of the gynoecium - synascidiate and simplicate. Respectively, placentation is of doubled type - axile in the lower part of the ovary and parietal in the upper one. We determined the presence of two vertical zones in the ovary of the studied species, though the ratio of heights of these zones differs. Therefore, the proportion of the synascidiate and simplicate zones in G. nivalis is 1:4.0, and in $L$. vernum 1:7.4. That is the relative height of the simplicate zone in $L$. vernum is almost twice greater than in G. nivalis. Taking into account the absence of a hemi-simplicate zone, we consider the gynoecium of the studied species eusyncarpous according to Leinfellner (1950), with both fertile zones of the ovary. Such conclusions were drawn by Shamrov (2010) after studying the development of the gynoecium in species of the Allium which is now classified to the Amaryllidaceae family.

The Amaryllidaceae family has the tendency towards formation of indehiscent fleshy capsules and berry-like fruits, which are seen repeatedly (Rasmussen et al., 2006; Takhtajan, 2009; Thadeo et al., 2015). This tendency was studied in different representatives with intermediate between dry and fleshy types of fruits among Monocotyledons (Rasmussen et al., 2006; Thadeo et al., 2015). Therefore, as mentioned above, the fruits of $G$. nivalis are fleshy throughout their development and remain such during the dissemination. In the dorsal carpel bundle of $G$. nivalis, the xylem has a V-like shape, while such structure was not seen in the outer bundles of the dorsal veins (Rasmussen et al., 2006). The double pattern of dorsal bundles of the carpels and lignified inner layers are the most frequent features of the loculicidal capsules (Roth, 1977).

The inner epidermis of the wall of the fruit (endocarp) of G. nivalis has no thickenings in the walls of the cells, while the outer epidermis (exocarp) has thin initial cellular walls with clearly notable cuticle. In the post-anthetic phase of the development of the flower, in the mesocarp, intercellular cavities occur which form spongy tissue of the fruit - fleshy capsule. Fruits of G. nivalis open in the conditions of significant moisture (Rasmussen et al., 2006), indicating different mechanism of fruit dehiscence from dry fruits - hygrochastic mechanism (Roth, 1977). The research revealed that the median (dorsal) bundle of the carpel adjoins directly to the lignified endocarp in the surveyed taxa with dehiscent fruits, whereas the indehiscent fruits had a layer of mesocarp between the dorsal bundle and lignified endocarp (Rasmussen et al., 2006). According of our data, the dorsal bundle of the carpel with doubled xylem and endocarp are separated by at least three layers of small cells in $G$. nivalis and 8 layers of cells of mesocarp in $L$. vernum (Fig. $3 \mathrm{c}, 5 \mathrm{~b}$ ). The fruit of $L$. vernum is defined as a dry capsule which contains endocarp with U-like thickening of the cells' walls, which is characteristic for many fruits of Liliidae subclass. Near the central column, the ovaries of endocarp cells are replaced by smaller cells with non-thickening walls. During the dehiscence of fruit, the central column disrupts (Rasmussen et al., 2006). In view of the uncertainty of the obtained data, further study is needed concerning the morphogenesis of fruits of G. nivalis and $L$. vernum and determining the pattern of the anatomical adaptations of fruits of these species to dehiscence.

The new peculiarities of anatomical structure of flower of $G$. nivalis and $L$. vernum which we determined are the presence of airy parenchyma in all parts of flower, and not only in the tepals and the wall of the ovary. In particular, we found presence of airy parenchyma in the ovules, which had not been reported before (Meerow \& Snijman, 1998; Rasmussen et al., 2006; Thadeo et al., 2015). We consider such peculiarity the result of the fast rate of growth of the flowers of $G$. nivalis and $L$. vernum during the short period of blossoming and necessity of increased aeration of parts of the shoot in the conditions of spring floods in the period of vegetation of these plants.

Flowers of G. nivalis and $L$. vernum have features of similarity with flowers characteristic of pollination by representatives of Apidae during buzz-pollintion; in particular, the anthers open apically, the resonating chamber of tepals around the stamens, and dry powdery pollen (Corbet et al., 1988; Dellinger et al., 2019). Such flowers are characteristic particularly for genera Polygonatum, Solanum, Borago and other plants pollinated by bees. The small amount of nectar, absence of septal nectaries in flowers of $G$. nivalis and $L$. vernum confirm the assumption that the main reward to the pollinator in these species is pollen and not nectar. However, anthecological peculiarities of flowers pollinated during vibration are practically unstudied (De Luca \& Vallejo-Marn, 2013). The Amaryllidaceae family is reported to have flowers of Solanum-type, which corresponds to the structure of flowers in G. nivalis and $L$. vernum and confirms our assumption about the way of pollination of these species.

\section{Conclusion}

The data we obtained helped deepen the knowledge on micromorphological and anatomical peculiarities of flowers of $G$. nivalis and L. vernum; in particular we elaborated the anatomical structure of tepals, the way of dehiscence of anthers, vertical zonation and type of gynoecium and type of placentation. The ovary was found to have features of early stages of morphogenesis of fruit and adaptation to dehiscence - differentiation of mesocarp and cells of endocarp, bifurcate dorsal bundles of carpels. We assume that the indicated peculiarities of the structure of the flower are associated with offering pollen as a reward to the pollinator. Because the ovary is the structural base of the fruit, histological differentiation of the wall of the ovary reflects the peculiarities of further morphogenesis of fruit. Anatomical structure of the ovaries of G. nivalis and $L$. vernum is characteristic for fleshy fruits with various levels of reduction of lignified tissues in the pericarp. The succulent character of the fruit is substantiated by the presence of numerous vascular bundles in the pericarp, multi-bundle traces of the tepals and airy parenchyma in the mesocarp. Further research should determine the post-anthetic peculiarities of the fruits of $G$. nivalis and $L$. vernum and their adaptations to dehiscence.

\section{References}

Al-Faris, H. D. H., Bulduk, I., \& Kahraman, A. (2019). Biochemical and micro-morphoanatomical investigations on Leucojum aestivum L. Notulae Botanicae Horti Agrobotanici Cluj-Napoca, 47(4), 1382-1393.

Arslan, M., Yildirim, A. B., Ozkan, E., Oktelik, F. B., \& Turker, A. U. (2020). Monthly variation of pharmaceutically valuable alkaloids, galanthamine and lycorine, in summer snowflake (Leucojum aestivum L.). Fresenius Environmental Bulletin, 29(4A), 2670-2677.

Artjushenko, Z. T. (1970). Amarillisovyie (Amaryllidaceae Jaume St.-Hilaire) SSSR. Morfologiya, sistematika i ispolzovanie [Amaryllidaceae Jaume St.-Hilaire of USSR. Morphology, systematics and use]. Nauka, Leningrad (in Russian).

Bareka, E.-P., Kamari, G., \& Phitos, D. (2003). Cytogeographic study of the genus Leucojum (Amaryllidaceae) in Greece. Bocconea, 16(2), 529-536. 
Barykina, R. P., Veselova, T. D., Deviatov, A. G., Djalilova, H. H., Iljina, G. M., \& Chubatova, N. V. (2004). Spravochnik po botanicheskoy mikrotehnike. Osnovyi i metodyi [Handbook of the botanical microtechniques]. Moscow University Press, Moscow (in Russian).

Berkov, S., Codina, C., \& Bastida, J. (2012). The Genus Galanthus: A source of bioactive compounds. In: Venketeshwer, R. (Ed.). Phytochemicals - A global perspective of their role in nutrition and health. InTech, Rijeka. Pp. 235-253.

Chase, M. W., Christenhusz, M. J. M., Fay, M. F., Byng, J. W., Judd, W. S., Soltis, D. E., Mabberley, D. J., Sennikov, A. N., Soltis, P. S., \& Stevens, P. F. (2016). The angiosperm phylogeny group. An update of the angiosperm phylogeny group classification for the orders and families of flowering plants APG IV. Botanical Journal of the Linnean Society, 181, 1-20.

Chase, M. W., Reveal, J. L., \& Fay, M. F. (2009). A subfamilial classification for the expanded asparagalean families Amaryllidaceae, Asparagaceae and Xanthorrhoeaceae. Botanical Journal of the Linnean Society, 161(2), 132-136.

Corbet, S. A., Chapman, H., \& Saville, N. (1988). Vibratory pollen collection and flower form: Bumble-bees on Actinidia, Symphytum, Borago and Polygonatum. Functional Ecology, 2(2), 147-155.

Daumann, E. (1970). Das Blütennektarium der Monocotyledonen unter besonderer Berücksichtigung seiner systematischen und phylogenetischen. Bedeutung Feddes Repertorium, 80(7-8), 463-590.

De Luca, P. A., \& Vallejo-Marn, M. (2013). What's the 'buzz' about? The ecology and evolutionary significance of buzz-pollination. Current Opinion in Plant Biology, 16, 1-7.

Dellinger, A., Pöllabauer, L., Loreti, M., Czurda, J., \& Schönenberger, J. (2019). Testing functional hypotheses on poricidal anther dehiscence and heteranthery in buzz-pollinated flowers. Acta ZooBot Austria, 156, 197-214.

Erdelská, O. (2018). Reproduction of snowdrop (Galanthus nivalis L.) in West Slovakia. Thaiszia Journal of Botany, 28(1), 49-57.

Fishchuk, O., Odintsova, A., \& Sulborska, A. (2013). Gynoecium structure in Dracaena fragrans (L.) Ker Gawl., Sansevieria parva N. E. Brown and Sansevieria trifasciata Prain (Asparagaceae) with septal emphasis on the structure of the septal nectary. Acta Agrobotanica, 66(4), 55-64.

García, N., Meerow, A. W., Arroyo-Leuenberger, S., Oliveira, R. S., Dutilh, J. H., Soltis, P. S., \& Judd, W. S. (2019). Generic classification of Amaryllidaceae tribe Hippeastreae. Taxon, 68(3), 425-612.

Kohut, E., Kopor, Z., Nagy, B., Csoma, Z., \& Hadnagy, I. (2019). Evaluation of morphometric parameters in case of Leucojum vernum $\mathrm{L}$. from the peres fores in Velyka Dobron wildlife reserve, Western Ukraine. Acta Biologica Marisiensis Journal, 2(2), 26-35.

Leinfellner, W. (1950). Der Bauplan des syncarpen Gynoeceums. Oesterreichische. Botanische Zeitschrift, 97(3-5), 403-436.

Lipnicki, L., \& Gruszka, W. (2019). Locality of spring snowflake Leucoium vernum in Barlinek Forest. Institute of Nature Conservation, Polish Academy of Sciences, 75(2), 155-158.

Lledó, M. D., Davis, A. P., Crespo, M. B., Chase, M. W., \& Fay, M. F. (2004). Phylogenetic analysis of Leucojum and Galanthus (Amaryllidaceae) based on plastid matK and nuclear ribosomal spacer (ITS) DNA sequences and morphology. Plant Systematics and Evolution, 246(3), 223-243.
Meerow, A. W., \& Snijman, D. A. (1998). Amaryllidaceae. In: Kubitzki, K., Huber, H., Rudall, P. J. Stevens, P. S., \& Studzel, T. (Ed.). The families and genera of vascular plants. III. Flowering plants: Monocotyledons: Lilianae (except Orchidaceae). Springer, Berlin. Pp. 83-110.

Meerow, A. W., Francisco-Ortega, J., \& Schnell, R. J. (2006). Phylogenetic relationships and biogeography within the Eurasian clade of Amaryllidaceae based on plastid ndhF and nrDNA ITS sequences: Lineage sorting in a reticulate area? Systematic Botany, 31(1), 42-60.

Mosyakin, S. L., \& Fedoronchuk, M. M. (1999). Vascular plants of Ukraine. A nomenclatural checklist. Kholodny Institute of Botany, Kyiv.

Newton, R. J., Hay, F. R., \& Ellis, R. H. (2015). Ecophysiology of seed dormancy and the control of germination in early spring-flowering Galanthus nivalis and Narcissus pseudonarcissus (Amaryllidaceae). Botanical Journal of the Linnean Society, 177, 246-262

Novikoff, A., \& Odintsova, A. (2008). Some aspects of gynoecium morphology in three bromeliad species. Wulfenia, 15, 13-24.

Nuraliev, M. S., \& Sokoloff, D. D. (2014). Vaskulyarnaya anatomiya tsvetka kak istochnik informatsii ob evolyutsii pokryitosemennyih rasteniy: Istoriya izucheniya i sovremennyie predstavleniya [Floral vascular anatomy as a source of information on evolution of Angiosperms: History of study and current views]. Botanicheskiy Zhurnal, 99(2), 129-158 (in Russian).

Odintsova, A. (2013). Dva osnovnyh typy septalnyh nektarnykiv odnodolnyh [Two main types of septal nectaries in monocotyledons]. Visnyk Lvivskogo Universytetu, Seriya Biologichna, 61, 41-50 (in Ukrainian).

Odintsova, A., \& Fishchuk, O. (2017). The flower morphology in three Convallariaceae species with various attractive traits. Acta Agrobotanica, 70(1), 17051719.

Padureanu, S., \& Patras, A. (2020). Germination potential and pollen tube growth in Galanthus nivalis L. Flora, 264, 151556.

Rasmussen, F. N., Frederiksen, S., Johansen, B., Jorgensen, L. B., Petersen, G., \& Seberg, O. (2006). Fleshy fruits in liliflorous monocots. Aliso, 22(1), 135-147.

Roth, I. (1977). Fruits of Angiosperms. In: Encyclopedia of Plant Anatomy. Wulff. Berlin: G. Borntraeger, 10(1), 200-675.

Shamrov, I. I. (2010). Osobennosti formirovaniya sinkarpnyih ginetseya v nekotoryih odnodolnyih rasteniy [The peculiarities of syncarpous gynoecium formation in some monocotyledonous plants]. Botanicheskiy Zhurnal, 95(8), 1041-1070 (in Russian),

Smets, E. F., Ronse, De Craene, L. P., Caris, P., \& Rudall, P. (2000). Floral nectaries in Monocotyledons: Distribution and evolution. Monocots II: Systematics and Evolution. CSIRO, Melbourne. Pp. 230-240.

Sparks, T. H., Mizera, T., Wójtowicz, W., \& Tryjanowski, P. (2012). Synchrony in the phenology of a culturally iconic spring flower. International Journal of Biometeorology, 56, 407-409.

Takhtajan, A. (2009). Flowering Plants. 2nd ed. Springer.

Thadeo, M., Hampilos, K. E., \& Stevenson, D. W. (2015). Anatomy of fleshy fruits in the Monocots. American Journal of Botany, 102(11), 1-23.

Weryszko-Chmielewska, E., \& Chwil, M. (2010). Ecological adaptations of the floral structures of Galanthus nivalis L. Acta Agrobotanica, 63(2), 41-49. 